\title{
INFLUENCE OF GLASS FIBER POSTS AND CLASS III DIRECT RESTORATIONS ON THE RESISTANCE OF ANTERIOR TEETH
}

\author{
INFLUENCIA DE PINOS DE FIBRA DE VIDRO E RESTAURAÇÕES DIRETAS EM \\ CLASSE III NA RESISTENCIA DE DENTES ANTERIORES
}

\section{Bruna Carbonari MASSAFRA ${ }^{1}$; Dandara ANDERLE ${ }^{1}$; Doglas CECCHIN ${ }^{2}$; Bruno CARLINI JÚNIOR ${ }^{3}$; Matheus Albino SOUZA ${ }^{4}$; João Paulo DE CARLI ${ }^{5}$; Migueli DURIGON ${ }^{6}$; Ana Paula FARINA ${ }^{7}$}

1. DDS, Faculty of Dentistry, University of Passo Fundo, RS, Brazil; 2. PhD in Endodontics, Department of Endontics, Faculty of Dentistry, University of Passo Fundo, RS, Brazil; 3. PhD in Dental Clinic, Private Dental Clinic, Passo Fundo, RS, Brazil; 4. PhD in Endodontics, Department of Endontics, Faculty of Dentistry, University of Passo Fundo, RS, Brazil; 5. PhD in Stomatology, Department of Oral Medicine, Faculty of Dentistry, University of Passo Fundo, RS, Brazil. joaodecarli@upf.br; 6. PhD in Dental Clinic, Private Dental Clinic, Ibiaçá, RS, Brazil; 7. PhD in Restorative Dentistry, Department of Restorative Dentistry, Faculty of Dentistry, University of Passo Fundo, RS, Brazil

\begin{abstract}
This study objectives to evaluate the fracture strength of upper central incisors (UCI) restored with composite resin (CR) in Class III cavities and endodontically treated teeth with or without glass fiber post (GFP), analyzing their failure mode. Sixty human UCI were randomly divided into four experimental groups: endodontically treated teeth without GFP (G1), endodontically treated teeth with GFP (G2), teeth with mesial/distal Class III cavities restored with CR without GFP (G3), and teeth with mesial/distal Class III cavities restored with CR with GFP (G4). The samples were submitted to the fracture strength test in a universal testing machine with a compression shear load applied at speed of $1.0 \mathrm{~mm} / \mathrm{min}$ until fracture occurred. The data were submitted to one-way ANOVA $(\alpha=0.05)$ and the samples were analyzed for failure mode. The analysis did not show a significant statistical difference in fracture strength between the groups (p>0.05). The results showed that only endodontically treated teeth $(\mathrm{G} 1)(753.4 \mathrm{~N})$ presented behavior similar to teeth with GFP (G2) (702.1N). The same occurred when comparing teeth with Class III cavities without GFP (G3) $(670.2 \mathrm{~N})$ and with GFP $(\mathrm{G} 4)(746.1 \mathrm{~N})$. It can be concluded that glass fiber posts do not change the fracture strength of incisors with endodontic treatment and Class III cavities.
\end{abstract}

KEYWORDS: Cavities. Composite resins. Endodontically treated teeth. Fracture.

\section{INTRODUCTION}

Endodontically treated teeth with little remaining crown structure are considered more fragile than healthy teeth due to the loss of healthy dental structure (KARZOUN et al., 2015). In such cases, the use of an intraradicular post is indicated to promote retention to the future restoration. For many years, the cast metal cores (CMC) and the intraradicular metal posts were the only form of tooth retention (SMITH et al., 1998). However, research indicates that such posts may cause irreparable fractures (BARCELLOS et al., 2013; GUO et al., 2016), for requiring the wear of the dentin structure (CHUANG et al., 2010) and for presenting both a high modulus of elasticity (SANTOS-FILHO et al., 2008; FARINA et al., 2015 ) and the possibility of corrosion (LASSILA et al., 2004) thus limiting their use.

Glass fiber posts (GFP) have advantages over metal posts because they provide better aesthetics and dentin-like biomechanical properties
(GORACCI et al., 2007; MARTELLI et al., 2008; SANTOS-FILHO et al., 2008; MOSHARRAF et al., 2012; AMARNATH et al., 2015). Their retention is related to specific characteristics such as post length, type of cement used, and amount of remaining tooth structure (ALOMARI et al., 2011; MAKADE et al., 2011; INAGAKI et al., 2014; KHOROUSHI et al., 2016).

It is also known that the clinical applicability of GFP is directly related to the reconstruction of the dental element lost (MAKADE et al., 2011; AMBICA et al., 2013; WANDSCHER et al., 2014; REZAEI et al., 2015; RAHMAN et al., 2016). Thus, an intraradicular post should be selected with caution, verifying the amount of remaining tooth structure, root canal anatomy, post length and diameter, as well as the physical properties and modulus of elasticity (ALOMARI et al., 2011; HATTA et al., 2011; LE BELLRÖNNLÖF et al., 2011). The higher the amount of remaining crown, the higher the resistance of the dental element (ZOGHEIB et al., 2008; 
Influence of glass fiber...

ARUNPRADITKUL et al., 2009; CORRÊA et al., 2018) considering that the post length and the composite resin (CR) core do not significantly increase the fracture strength of endodontically treated teeth (VALLE et al., 2007).

However, in the case of gingival fractures between crown and root, there is a possibility of prosthetic reconstruction of the dental element, which does not occur in longitudinal or oblique fractures in the middle and cervical thirds of the root (BARCELLOS et al., 2013). Thus, the classification of the fracture pattern may be an important guide for the clinician to select the most suitable restorative protocol for the resolution of fractured teeth cases.

Therefore, this study aimed to evaluate fracture strength and failure mode in human upper central incisors in dental elements with or without GFP. The hypothesis tested was that GFP does not interfere with the fracture strength of endodontically treated teeth and restored Class III cavities.

\section{MATERIAL AND METHODS}

\section{Sample selection}

This project was approved by the Research Ethics Committee of the University of Passo Fundo (UPF), RS, Brazil (Protocols \# 886.261/2014 and 1.082.717/2015). Sixty human upper central incisors were collected from the Tooth Bank of the Faculty of Dentistry of UPF and the teeth recently extracted for periodontal reasons and with intact marginal ridges were selected. Teeth with Class IV or $\mathrm{V}$ lesions, erosion/abrasion lesions, excessively weakened, and with disparate dimensions were excluded from the study. After the selection, the dental elements were cleaned with periodontal curettes and ultrasound.

\section{Experimental groups}

After sample randomizations, the sixty central incisors were divided into four groups $(\mathrm{n}=15)$ :

Group I - Endodontically treated teeth without GFP. Group II - Endodontically treated teeth with GFP.

Group III - Endodontically treated teeth with mesial and distal Class III crown cavity (without involving the incisal angle) restored with CR without GFP in the root portion.

Group IV - Teeth with the same conditions of Group III, but with intraradicular GFP.

\section{Endodontic treatment}

MASSAFRA, B. C. et al.

The groups received endodontic treatment accessed with spherical diamond tips, establishing a triangular crown opening with the base facing the incisal aspect. The preparation of the cervical and middle thirds was performed with $\# 2$ and \#3 Largo $^{\mathrm{TM}}$ burs (Dentsply, Maillefer, Ballaigues, Switzerland) and instrumentation was performed using $1^{\text {st }}$-series K-Flex endodontic files (Dentsply, Maillefer, Ballaigues, Switzerland) with $2 \%$ chlorhexidine gel $\left(2 \%\right.$ Chlorhexidine $\mathrm{S}^{\mathrm{TM}}$, FGM, Joinville, SC, Brazil) as the auxiliary chemical substance. The root canals were filled with guttapercha cones and Endofill ${ }^{\mathrm{TM}}$ endodontic cement (Dentsply Maillefer, Ballaigues, Switzerland) using the lateral condensation technique. After the endodontic treatment, the teeth of groups II and IV received intraradicular GFP (White Post ${ }^{\mathrm{TM}}$, FGM, Joinville, SC, Brazil).

\section{GFP installation and restorative procedure}

For the groups that received GFP (II and IV), the following protocol was adopted: application of $37 \%$ phosphoric acid (Condac ${ }^{\mathrm{TM}}$, FGM, Joinville, $\mathrm{SC}$, Brazil) for $30 \mathrm{~s}$ in the root canal, washing and drying with absorbent paper cones (Endopoints ${ }^{\mathrm{TM}}$, Paraíba do Sul, RJ, Brazil). Then, the Scotchbond ${ }^{\mathrm{TM}}$ Multipurpose adhesive (3M ESPE, St. Paul, MN, USA) was applied to the root canal, followed by the removal of excesses and photopolymerization for 40 s. The posts from White Post ${ }^{\mathrm{TM}}$ were treated according to the manufacturer's instructions. So, the posts were disinfected with $70 \%$ alcohol and then silane (Prosil ${ }^{\mathrm{TM}}$, FGM, Joinville, SC, Brazil) was applied over the whole surface of the posts and the drying time of 1 minute was waited. After, the posts were cemented with resin cement (All Cem Core ${ }^{\mathrm{TM}}$, FGM, Joinville, SC, Brazil).

Next, the restorations were produced in groups III and IV. Prior to such restorations, the teeth were etched with $37 \%$ phosphoric acid for $30 \mathrm{~s}$ on enamel and $15 \mathrm{~s}$ on dentin. Then, the teeth were washed with water for 1 minute and dried with moistened cotton balls. Light air blasts on the buccal and palatal surfaces were used to assist the removal of excess moisture. A Singlebond $2^{\mathrm{TM}}$ adhesive layer (3M ESPETM, St. Paul, MN, USA) was applied and polymerized for 40 seconds on each aspect. The restorative process was initiated in the pulp chamber using small increments of $\mathrm{CR}$ in the $\mathrm{A} 2$ shade (Opallis $^{\mathrm{TM}}$, FGM, Joinville, SC, Brazil) and with approximately $2 \mathrm{~mm}$ in thickness, up to complete cavity filling, as shown in Figure 1. 


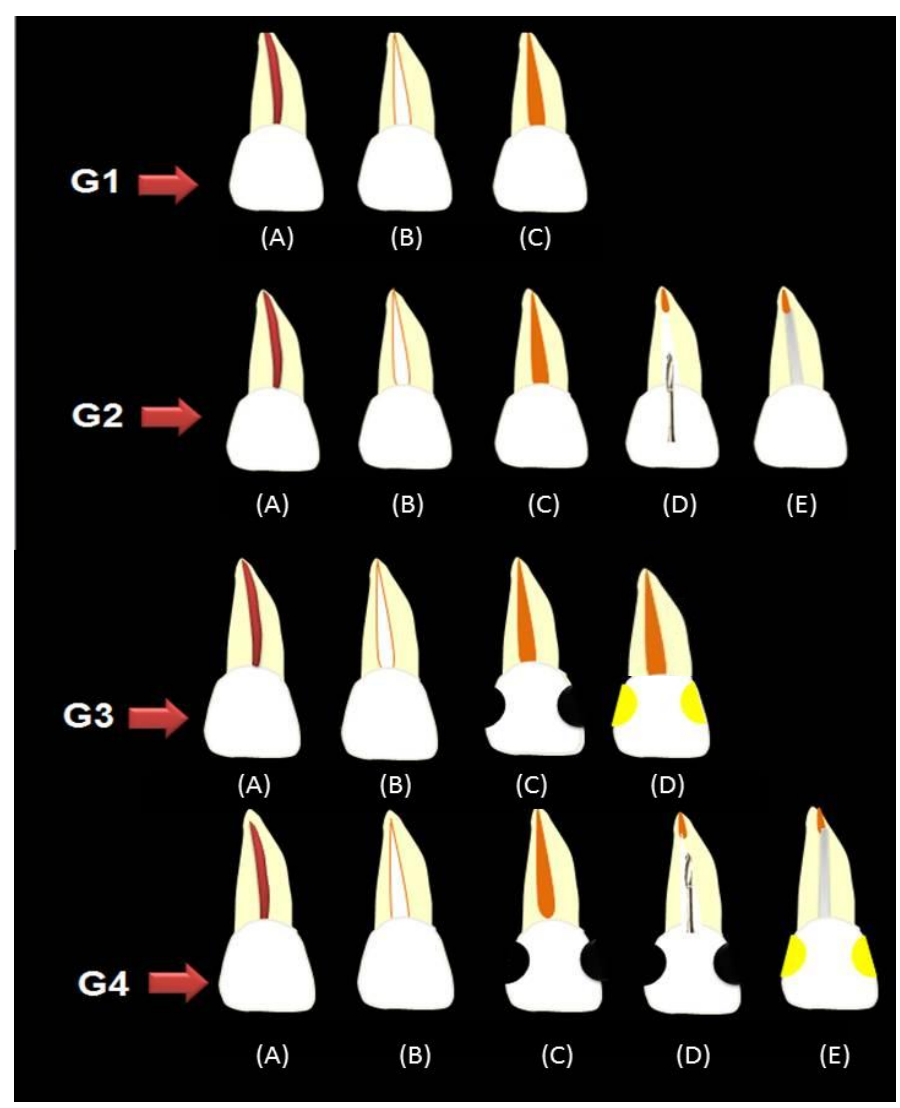

Figure 1. Diagram of the sample groups: All groups - (A) healthy tooth, (B) preparation of canals with Largo burs. Group 1 - (C) endodontically treated tooth. Group 2 - (C) endodontically treated tooth, (D) canal opening, (E) GFP cementation. Group 3 - (C) endodontically treated teeth with mesial and distal Class III cavity, (D) restored tooth. Group 4 - (C) endodontically treated teeth with mesial and distal Class III cavity, (D) canal opening, (E) tooth restored with GFP cementation.

\section{Inclusion of specimens and strength test}

All roots were inserted in colorless acrylic resin (Jet ${ }^{\mathrm{TM}}$, São Paulo, SP, Brazil) and poured into PVC rings (Tigre Brasil ${ }^{\mathrm{TM}}$, Osasco, SP, Brazil) with the aid of a dental surveyor (Bio-Art' ${ }^{\mathrm{TM}}$, São Carlos, SP, Brazil) for a standard positioning of the teeth. Small depressions on the palatal face of the teeth were produced with half the active tip of a diamond spherical drill 1011 (KG Sorensen ${ }^{\mathrm{TM}}$, Cotia, SP, Brazil) for supporting the application of compressive load. Such depressions were made in the center of the palatal concavity in order not to cause stress zones in the teeth. The samples were submitted to a compression shear load test in a universal testing machine (EMIC DL 2000 ${ }^{\mathrm{TM}}$, São Jose dos Pinhais, PR, Brazil). The specimens remained at an approximate inclination of $135^{\circ}$ (CECCHIN et al., 2010; CARLINI-JUNIOR et al., 2011; BARCELLOS et al., 2013), with the force applied at speed of $1 \mathrm{~mm} / \mathrm{min}$ until fracture, using a constant load.

The failure modes were classified as longitudinal or transverse, as described next: Type 1 (T1) - fracture at the cementoenamel junction; Type
2 (T2) - transverse fracture in the cervical third; Type 3 (T3) - transverse fracture in the middle third; Type 4 - (T4) transverse fracture in the apical third; Type 5 - (T5) longitudinal fracture (in the long axis of the tooth). The fractures were also divided according to the possibility of reconstruction in Type A - Repairable (fracture favorable to posterior reconstruction: T1 and T2) and Type B - Irreparable (longitudinal or oblique radicular fractures resulting in exodontia: T3, T4, and T5) (GUO et al., 2016), according to Figure 2.

\section{Statistical analysis}

The normal distribution of the fracture strength data was confirmed by the KolmogorovSmirnov test $(p>0.05)$. Data were evaluated by oneway ANOVA. Failure mode distribution was evaluated by the chi-square test $(\alpha=0.05)$. Data were analyzed using Stat Plus AnalystSoft Inc. version 6.0 (Vancouver, BC, Canada). 


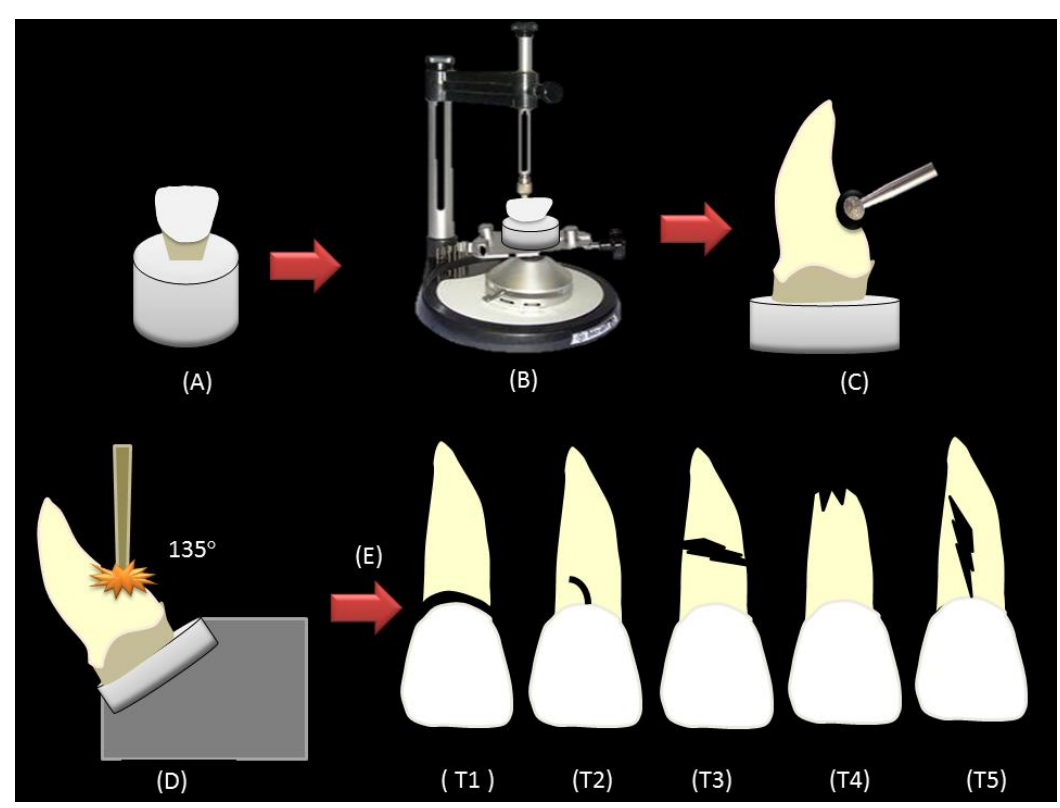

Figure 2. Strength test and classification of failure modes. (A) insertion of samples in acrylic resin PVC cylinders, (B) positioning of the sample, (C) production of the palatal small depressions, (D) fracture strength test (Emic), (E) classification of failure modes ( $\mathrm{T}=$ fracture type).

\section{RESULTS}

Table 1 presents the means and standard deviations related to the fracture strength $(\mathrm{N})$ test. The one-way ANOVA showed a value of $\mathrm{p}=0.6426$, meaning there was no statistical difference between the groups evaluated (Table 1).
Table 2 shows the data regarding the failure mode and the possibility of repair (A: repairable and B: irreparable). Overall, it was possible to observe a greater amount of T3 failure. Regarding the possibility of repair, most of the samples presented irreparable fractures.

Table 1. Mean and standard deviations of the fracture analysis in each sample group.

\begin{tabular}{lll}
\hline Groups & Means (SD) (N) & Statistics (ANOVA/Tukey's) \\
\hline G1 - Without GFP & $753.4( \pm 267.5)$ & A \\
G2 - With GFP & $702.1( \pm 328.4)$ & A \\
G3 - CIII without GFP & $670.2( \pm 175.5)$ & A \\
G4 - CIII with GFP & $746.9( \pm 239.9)$ & A \\
\hline
\end{tabular}

*Equal letters represent no statistical difference between the groups $(\mathrm{p}>0.05)$.

Table 2. Failure mode distribution and possibility of repair in experimental groups.

\begin{tabular}{llllllll}
\hline Groups & T1(\%) & T2(\%) & T3(\%) & T4(\%) & T5(\%) & Repairable(\%) & Irreparable(\%) \\
\hline G1: Without GFP & $1(6.7)$ & $3(20)$ & $7(46.6)$ & $4(26.7)$ & $0(0)$ & $5(33.3)$ & $10(66.7)$ \\
G2: With GFP & $0(0)$ & $4(26.7)$ & $11(73.3)$ & $0(0)$ & $0(0)$ & $4(26.7)$ & $11(73.3)$ \\
G3: CIII without GFP & $0(0)$ & $4(26.7)$ & $10(66.6)$ & $1(6.7)$ & $0(0)$ & $4(26.7)$ & $11(73.3)$ \\
G4: CIII with GFP & $0(0)$ & $6(40)$ & $9(60)$ & $0(0)$ & $0(0)$ & $6(40)$ & $9(60)$ \\
\hline Total & $1(1.7)$ & $17(28.3)$ & $37(61.7)$ & $5(8.3)$ & $0(0)$ & $19(31.7)$ & $41(68.3)$
\end{tabular}

*Failure mode data were tabulated and evaluated statistically by the chi-square test, with no difference between G1 and G2 (p=0.1967) or between $\mathrm{G} 3$ and $\mathrm{G} 4(\mathrm{p}=0.835)$. 


\section{DISCUSSION}

Glass fiber posts (GFP) are widely used to restore anterior teeth (NAUMANN et al., 2012; STERZENBACH et al., 2012) because they present a modulus of elasticity similar to that of dentin (LASSILA et al., 2004; DIETSCHI et al., 2007; ZICARI et al., 2013), contrary to the cast metal cores (CMC) that require higher root dentin wear, a greater number of clinical sessions for preparation, and present a modulus of elasticity around $200 \mathrm{GPa}$, which increases the chances of fracture of the dental element (ARTOPOULOU et al., 2006; SARKISONOFRE et al., 2014). Hence, Murali Mohan et al. (2015), affirm that the use of CMC causes stress concentration, which may produce dental fractures in up to $91 \%$ of the cases of their use.

The present study evaluated the influence of GFP on the fracture strength of endodontically treated teeth with marginal ridges, which absence might affect the resistance of the dental element, considering that such fracture strength depends mainly on the amount of remaining crown structure (MONDELLI et al., 1980). According to Corrêa et al. (2018), in the absence of remaining crown structure in anterior teeth, the fracture strength values tend to be lower than in teeth with remaining crown structure.

Glass fiber posts contain a structure of fibers that provide high tensile strength and a resin matrix capable of withstanding compressive forces, composed of an epoxy or bis-GMA resin (bisphenol glycidyl methacrylate), and the posts are noncorrosive and have a modulus of elasticity similar to that of dentin (FERRARI et al., 2007).

The present study shows that the GFP does not interfere with the fracture strength of teeth with crowns weakened by Class III restorations on the proximal surfaces. These data corroborate previous studies (VALDIVIA et al., 2012; ABDULJAWAD et al., 2017; STEIN-LAUSNITZ et al., 2019). The results of the present study allow suggest that when an anterior tooth element presents Class III restorations, the use of GFP is not required to retain the restoration, similar to that stated by Lima et al. (2010).

On the other hand, differing from the findings obtained in this research, Scotti et al. (2015) affirm that endodontically treated posterior teeth with GFP showed an increase in fracture strength. Additionally, Ayna et al. (2018) report that GFP may be used clinically to aid the retention of $\mathrm{CR}$ restorations, increasing the resistance of the tooth/restoration set.

Corrêa et al. (2018) state that teeth with GFP are more prone to repairable fractures when compared to teeth with cast metal core. Despite that, in the analysis of the failure modes realized in the present study, it was observed that most of them were irreparable (even on teeth with GFP) and located in the middle third of the teeth, agreeing with the findings by Hayashi et al. (2006).

In this study, most of the samples (with or without GFP) presented irreparable fractures and no statistical difference was observed in the failure mode between groups. Thus, it may be suggest that teeth with GFP present types of fractures similar to teeth with endodontic treatment without intraradicular retainers. These results differ from the findings by Seraj et al. (2015), who tested three types of prefabricated posts and found favorable fractures as the most frequent mode in both groups.

From the results found in this research, it may be suggest that anterior teeth with direct Class III restorations associated with GFP present the same fracture strength value and the same failure mode as restored teeth without posts. Thus, in teeth with satisfactory remaining dental crown, the use of GFP is not indicated. Studies such as by Alomari et al. (2011) show that the use of posts promotes a significant loss of dentin structure in endodontically treated incisors and the use of GFP is indicated in cases of extensive dental crown loss.

\section{CONCLUSIONS}

The use of GFP in anterior teeth is not required when such teeth present crowns weakened by Class III restorations.

Anterior teeth with GFP present strength and failure modes similar to endodontically treated teeth without intraradicular posts, and the use of GFP is not required when there is a satisfactory remaining dental crown.

Class III restorations in anterior teeth without intraradicular retainers were not a decisive factor for either the reduction of fracture strength or the variation of failure modes.

RESUMO: Este estudo objetiva avaliar a resistência à fratura de incisivos centrais superiores (ICS) restaurados com resina composta (RC) em cavidades Classe III e dentes tratados endodonticamente com ou sem pino de fibra de vidro (PFV), analisando seu padrão de fratura. Sessenta ICS humanos foram divididos aleatoriamente em quatro grupos experimentais: dentes tratados endodonticamente sem PFV (G1), dentes 
tratados endodonticamente com PFV (G2), dentes com cavidades mesiais/distais Classe III restauradas com RC sem PFV (G3), e dentes com cavidades mesiais/distais Classe III restauradas com RC com PFV (G4). As amostras foram submetidas ao teste de resistência à fratura em uma máquina universal de ensaios com uma carga de cisalhamento de compressão aplicada na velocidade de $1,0 \mathrm{~mm} / \mathrm{min}$ até a ocorrência da fratura. Os dados foram submetidos à ANOVA unidirecional $(\alpha=0,05)$ e as amostras foram analisadas quanto ao modo de falha. A análise não mostrou diferença estatisticamente significativa na resistência à fratura entre os grupos $(\mathrm{p}>0,05)$. Os resultados mostraram que os dentes apenas tratados endodonticamente (G1) $(753,4 \mathrm{~N})$ apresentaram comportamento semelhante aos dentes com PFV (G2) $(702,1 \mathrm{~N})$. O mesmo ocorreu ao comparar dentes com cavidades Classe III sem PFV (G3) (670.2 N) e com PFV (G4) (746.1N). Pode-se concluir que pinos de fibra de vidro não alteram a resistência à fratura de incisivos com tratamento endodôntico e cavidades Classe III.

PALAVRAS-CHAVE: Cavidade. Resinas compostas. Dentes tratados endodonticamente. Fratura.

\section{REFERENCES}

ABDULJAWAD, M.; SAMRAN, A.; KADOUR, J.; KARZOUN, W.; KERN, M. Effect of fiber posts on the fracture resistance of maxillary central incisors with class III restorations: an in vitro study. J. Prosthet. Dent., v. 118, n. 1, p. 55-60, 2017. https://doi.org/10.1016/j.prosdent.2016.09.013

ALOMARI, Q. D.; BARRIESHI, K. M.; AL-AWADHI, S. A. Effect of post length and diameter on remaining dentine thickness in maxillary central and lateral incisors. Int. Endod. J., v. 44, n. 10, p. 956-966, 2011. https://doi.org/10.1111/j.1365-2591.2011.01917.x

AMARNATH, G. S.; PANDEY, A.; PRASAD, H. A.; HILAL, M. Comparative evaluation of enhancing retention of dislodged crown using preparation modifications and luting cements: an in-vitro study. J. Int. Oral Health, v. 7, n. 8, p. 47-51, 2015.

AMBICA, K.; MAHENDRAN, K.; TALWAR, S.; VERMA, M.; PADMINI, G.; PERIASAMY, R. Comparative evaluation of fracture resistance under static and fatigue loading of endodontically treated teeth restored with carbon fiber posts, glass fiber posts, and an experimental dentin post system: an in vitro study. $\mathbf{J}$ Endod. v. 39, n. 1, p. 96-100, 2013. https://doi.org/10.1016/j.joen.2012.07.003

ARTOPOULOU, I. I.; O'KEEFE, K. L.; POWERS, K. M. Effect of core diameter and surface treatment on the retention of resin composite cores t prefabricated endodontics post. J. Prosthodont., v. 15, n. 3, p. 172-179, 2006. https://doi.org/10.1111/j.1532-849X.2006.00097.x

ARUNPRADITKUL, S.; SAENGSANON, S.; PAKVIWAT, W. Fracture resistance of endodontically treated teeth: three walls versus four walls of remaining coronal tooth structure. J. Prosthodont., v. 18, n. 1, p. 49-53, 2009. https://doi.org/10.1111/j.1532-849X.2008.00375.x

AYNA, B.; AYNA, E.; ÇELENK, S.; BAŞARAN, E. G.; YILMAZ, B. D.; TACIR, I. H. et al. Comparison of the clinical efficacy of two different types of post systems which were restored with composite restorations.

World J. Clin. Cases, v. 6, n. 3, p. 27-34, 2018. https://doi.org/10.12998/wjcc.v6.i3.27

BARCELlOS, R. R.; CORREIA, D. P.; FARINA, A. P.; MESQUITA, M. F.; FERRAZ, C. C.; CECCHIN, D. Fracture resistance of endodontically treated teeth restored with intra-radicular post: The effects of post system and dentine thickness. J. Biomech., v. 46, n. 15, p. 2572-2577, 2013.

https://doi.org/10.1016/j.jbiomech.2013.08.016

CARLINI-JUNIOR, B.; CECCHIN, D.; PEREIRA, G. D.; PAILILLO, L. A. Influence of remaining coronal structure and finish line on the fracture strength of roots restored with metallic posts. Braz. Oral Res., v. 25, n. 4, p. 345-350, 2011. https://doi.org/10.1590/S1806-83242011000400011 
CECCHIN, D.; FARINA, A. P.; GUERREIRO, C. A.; CARLINI-JR, B. Fracture resistance of roots prosthetically restored with intra-radicular posts of different lengths. J. Oral Rehabil., v. 37, n. 2, p. 116-122, 2010. https://doi.org/10.1111/j.1365-2842.2009.02028.x

CHUANG, S. F.; YAMAN, P.; HERRERO, A.; DENNISON, J. B.; CHANG, C. H. Influence of post material and length on endodontically treated incisors: an in vitro and finite element study. J. Prosthet. Dent., v. 104, n. 6, p. 379-388, 2010. https://doi.org/10.1016/S0022-3913(10)60171-0

CORREAA, G.; BRONDANI, L. P.; WANDSCHER, V. F.; PEREIRA, C. K. R.; VALANDRO, L. F.; BERGOLI, C. D. Influence of remaining coronal thickness and height on biomechanical behavior of endodontically treated teeth: survival rates, load to fracture and finite element analysis. J. Appl. Oral Sci., v. 26, n. 7, p. 1-11, 2018. https://doi.org/10.1590/1678-7757-2017-0313

DIETSCHI, D.; DUC, O.; KREJCI, I.; SADAN, A. Biomechanical considerations for the restoration of endodontically treated teeth: a systematic review of the literature--Part 1. Composition and micro- and macrostructure alterations. Quintessence Int., v. 38, n. 9, p. 733-143, 2007.

FARINA, A. P.; WEBER, A. L.; SEVERO, B. P.; SOUZA, M. A.; CECCHIN, D. Effect of length post and remaining root tissue on fracture resistance of fibre posts relined with resin composite. J. Oral Rehabil., v. 42, n. 3, p. 202-208, 2015. https://doi.org/10.1111/joor.12243

FERRARI, M.; CAGIDIACO, M. C.; GRANDINI, S.; DE SANCTIS, M.; GORACCI, C. Post Placement Affects Survival of Endodontically Treated Premolars. J. Dent. Res., v. 86, n. 8, p. 729-734, 2007. https://doi.org/10.1177/154405910708600808

GORACCI, C.; GRANDINI, S.; BOSSÙ, M.; BERTELLI, E.; FERRARI, M. Laboratory assessment of the retentive potential of adhesive posts: a review. J. Dent., v. 35, n. 11, p. 827-835, 2007. https://doi.org/10.1016/j.jdent.2007.07.009

GUO, J.; WANG, Z.; XUESHENG, L.; CHAOYANG, S.; GAO, E.; HONGBO, L. A. A comparison of the fracture resistances of endodontically treated mandibular premolars restored with endocrown and glass fiber post-core retrained conventional crowns. J. Adv. Prosthodont., v. 8, n. 6, p. 489-493, 2016. https://doi.org/10.4047/jap.2016.8.6.489

HATTA, M.; SHINYA, A.; VALLITTU, P. K.; SHINYA, A.; LASSILA, L. V. High volume individual fibre post versus low volume fibre post: The fracture load of the restored tooth. J. Dent., v. 39, n. 1, p. 65-71, 2011. https://doi.org/10.1016/j.jdent.2010.10.004

HAYASHI, M.; TAKAHASHI, Y.; IMAZATO, S.; EBISU, S. Fracture resistance of pulpless teeth restored with post-cores and crowns. Dent. Mater., v. 22, n. 5, p. 477-485, 2006.

https://doi.org/10.1016/j.dental.2005.03.017

INAGAKI, T.; KOMADA, W.; NEMOTO, R.; YOSHIDA, K.; MIURA, H. Influence of post and core materials on distortion around 4-unit zirconia bridge margins. Dent. Mater. J., v. 33, n. 3, p. 373-382, 2014. https://doi.org/10.4012/dmj.2013-306

KARZOUN, W.; ABDULKARIM, A.; SAMRAN, A.; KERN, M. Fracture strength of endodontically treated maxillary premolars supported by a horizontal glass fiber post: an in vitro study. J. Endod., v. 41, n. 6, p. 907912, 2015. https://doi.org/10.1016/j.joen.2015.01.022

KHOROUSHI, M.; SHEIKHI, M.; KHALILIAN-GOURTANI, A.; SOLEIMANI, B. Effect of root canal rinsing protocol on dentin bond strength of two resin cements using three different method of test. J. Clin. Exp. Dent., v. 18, n. 3, p. 246-254, 2016. https://doi.org/10.4317/jced.52674 
LASSILA, L. V.; TANNER, J.; LE BELL, A. M.; NARVA, K.; VALLITTU, P. K. Flexural properties of fiber reinforced root canal post. Dent. Mater., v. 20, n. 1, p.29-36, 2004. https://doi.org/10.1016/S01095641(03)00065-4

LE BELL-RÖNNLÖF, A. M.; LASSILA, L. V.; KANGASNIEMI, I.; VALLITTU, P. K. Load-bearing capacity of human incisor restored with various fiber-reinforced composite posts. Dent. Mater., v. 27, n. 6, p. 107-115, 2011. https://doi.org/10.1016/j.dental.2011.02.009

LIMA, A. F.; SPAZZIN, A. O.; GALAFASSI, D.; CORRER-SOBRINHO, L.; CARLINI-JÚNIOR, B. Influence of ferrule preparation with or without glass fiber post on fracture resistance of endodontically treated teeth. J. Appl. Oral Sci., v. 18, n. 4, p. 360-362, 2010. https://doi.org/10.1590/S1678-77572010000400007

MAKADE, C. S.; MESHRAM, G. K.; WARHADPANDE, M.; PATIL, P. G. A comparative evaluation of fracture resistance of endodontically treated teeth restored with different post core systems - an in-vitro study. J. Adv. Prosthodont., v. 3, n. 2, p. 90-95, 2011. doi: 10.4047/jap.2011.3.2.90

MARTELLI, H. JR.; PELLIZZER, E. P.; ROSA, B. T.; LOPES, M. B.; GONINI, A. JR. Fracture Resistance of Structurally compromised root filled bovine teeth restored with accessory glass fibre posts. Int. Endod. J., v. 41, n. 8, p. 685-692, 2008. https://doi.org/10.1111/j.1365-2591.2008.01424.x

MONDELLI, J.; STEAGALL, L.; ISHIKIRIAMA, A.; NAVARRO, M. F. L.; SOARES, F. B. Fracture strength of human teeth with cavity preparations. J. Prosthet. Dent., v. 43, n. 4, p. 419-422, 1980. https://doi.org/10.1016/0022-3913(80)90213-9

MOSHARRAF, R.; BAGHAEI YAZDI, N. Comparative evaluation of effects of different surface treatment methods on bond strength between fiber post and composite core. J. Adv. Prosthodont., v. 4, n. 2, p. 103-108, 2012. https://doi.org/10.4047/jap.2012.4.2.103

MURALI MOHAN, S.; MAHESH GOWDA, E.; SHASHIDHAR, M. P. Clinical evaluation of the fiber post and direct composite resin restoration for fixed single crowns on endodontically treated teeth. Med. J. Armed Forces India, v. 71, n. 3, p. 259-264, 2015. https://doi.org/10.1016/j.mjafi.2012.02.007

NAUMANN, M.; KOELPIN, M.; BEUER, F.; MEYER-LUECKEL, H. 10-year survival evaluation for glassfiber-supported postendodontic restoration: a prospective observational clinical study. J. Endod., v. 38, n. 4, p. 432-435, 2012. https://doi.org/10.1016/j.joen.2012.01.003

RAHMAN, H.; SINGH, S.; CHANDRA, A.; CHANDRA, R.; TRIPATHI, S. Evaluation of fracture resistance of endodontically treated teeth restored with composite resin along with fibre insertion in different positions in vitro. Aust. Endod. J., v. 42, n. 2, p. 60-65, 2016. https://doi.org/10.1111/aej.12127

REZAEI DASTJERDI, M.; AMIRIAN CHAIJAN, K.; TAVANAFAR, S. Fracture resistance of upper central incisors restored with different posts and cores. Restor. Dent. Endod., v. 40, n. 3, p. 229-235, 2015. https://doi.org/10.5395/rde.2015.40.3.229

SANTOS-FILHO, P. C. F.; CASTRO, C. G.; SILVA, G. R.; CAMPOS, R. E.; SOARES, C. J. Effect of post system length on the strain and fracture resistance of root filled bovine teeth. Int. Endod. J., v. 41, n. 6, p. 493501, 2008. https://doi.org/10.1111/j.1365-2591.2008.01383.x

SARKIS-ONOFRE, R.; JACINTO, R. C.; BOSCATO, N.; CENCI, M. S.; PEREIRA-CENCI, T. Cast metal vs. glass fiber posts: a randomized controlled trial with up to 3 years of follow up. J. Dent., v. 42, n. 5, p. 582-587, 2014. https://doi.org/10.1016/j.jdent.2014.02.003

SCOTTI, N.; ERULI, C.; COMBA, A.; PAOLINO, D. S.; ALOVISI, M.; PASQUALINI, D. et al. Longevity of class 2 direct restorations in rootfilled teeth: a retrospective clinical study. J. Dent., v. 43, n. 5, p. 499-505, 2015. https://doi.org/10.1016/j.jdent.2015.02.006 
SERAJ, B.; GHADIMI, S.; ESTAKI, Z.; FATEMI, M. Fracture resistance of three different posts in restoration of severely damaged primary anterior teeth: An in vitro study. Dent. Res. J., v. 12, n, 4, p. 372-378, 2015. https://doi.org/10.4103/1735-3327.161461

SMITH, C. T.; SCHUMAN, N. J.; WASSON, W. Biomechanical criteria for evaluating prefabricated post-andcore systems: A guide for the restorative dentist. Quintessence Int., v. 29, n. 5, p. 305-312, 1998.

STEIN-LAUSNITZ, M.; BRUHNKE, M.; ROSENTRITT, M.; STERZENBACH, G.; BITTER, K.; FRANKENBERGER, R. et al. Direct restoration of endodontically treated maxillary central incisors: post or no post at all? Clin. Oral Investig., v. 23, n. 1, p. 382-389, 2019. https://doi.org/10.1007/s00784-018-2446-6

STERZENBACH, G.; FRANKE, A.; NAUMANN, M. Rigid versus flexible dentine-like endodontic postsclinical testing of a biomechanical concept: seven-year results of a randomized controlled clinical pilot trial on endodontically treated abutment teeth with severe hard tissue loss. J. Endod., v. 38, n. 12, p. 1557-1563, 2012. https://doi.org/10.1016/j.joen.2012.08.015

VALDIVIA, A. D.; RAPOSO, L. H.; SIMAMOTO-JUNIOR, P. C.; NOVAIS, V. R.; SOARES, C. J. The effect of fiber post presence and restorative technique on the biomechanical behavior of endodontically treated maxillary incisors: an in vitro study. J. Prosthet. Dent., v. 108, n. 3, p. 147-157, 2012. https://doi.org/10.1016/S0022-3913(12)60138-3

VALLE, A. L.; PEREIRA, J. R.; SHIRATORI, F. K.; PEGORARO, F.; BONFANTE, G. Comparison of the fracture resistance of endodontically treated teeth restored with prefabricated posts and composite resin cores with different post lengths. J. Appl. Oral Sci., v. 15, n. 1, p. 29-32, 2007. https://doi.org/10.1590/S167877572007000100007

WANDSCHER, V. F.; BERGOLI, C. D.; LIMBERGER, I. F.; ARDENGHI, T. M.; VALANDRO, L. F. Preliminary results of the survival and fracture load of roots restored with intracanal posts: weakened vs nonweakened roots. Oper. Dent., v. 39, n. 5, p. 541-555, 2014. https://doi.org/10.2341/12-465

ZICARI, F.; COUTINHO, E.; SCOTTI, R.; VAN MEERBEEK, B.; NAERT, I. Mechanical properties and micro-morphology of fiber posts. Dent. Mater., v. 29, n. 4, p. 45-52, 2013.

https://doi.org/10.1016/j.dental.2012.11.001

ZOGHEIB, L. V.; PEREIRA, J. R.; DO VALLE, A. L.; DE OLIVEIRA, J. A.; PEGORARO, L. F. Fracture Resistance of Weakened Roots Restored with Composite Resin and Glass Fiber Post. Braz. Dent. J., v. 19, n. 4, p.329-333, 2008. https://doi.org/10.1590/S0103-64402008000400008 